\title{
Livelihood diversification in a rural community of the Okavango Delta, Botswana. - Results from a Socio-Economic Baseline Survey.
}

\author{
Björn Herold, Laura M. Grosse, Stephanie Domptail, Donald L. Kgathi, Thomas Falk, \\ Nadege Azebaze \& Benjamin Kowalski
}

\begin{abstract}
Due to a special mixture of influencing factors and basic conditions, livelihood strategies in the village of Seronga are highly diversified. The remote location of Seronga at the northern edge of the Okavango Delta distances the population from urban centers and modernity. Therefore, agricultural production and livestock keeping remain the main basis of subsistence for the majority of the population. At the same time, manifold connections to bigger cities, the presence of tourism and increasing market integration bridge this gap, transforming desires, aspirations, and claims. Consequently, the need to adapt livelihood strategies towards cash income generation emerges. In this paper we combine qualitative methods and new quantitative data from the "The Future Okavango" (TFO) Socio-Economic Baseline Survey (SEBS) to highlight the composition of livelihood strategies in the community of Seronga. Using the Sustainable Livelihood Framework we draw special attention to transformation tendencies, to the socio-economic stratification of livelihood strategies, and to the resulting differences in vulnerability and sustainability for the households of Seronga..
\end{abstract}

Keywords: expenditure; household economies; income; livelihood strategies; modernity; sustainability; social stratification; socio-economic baseline survey; vulnerability.

Abbreviations: ARAP (Accelerated Rainfed Agricultural Program); BMC (Botswana Meat Commission); BAMB (Botswana Agricultural Marketing Board); CBNRM (Community Based Natural Resource Management); DFID (Department for International Development); NHIES (National Household Income and Expenditure Survey); OPT (Okavango Polers Trust); SEBS (Socio-Economic Baseline Survey); SLF (Sustainable Livelihoods Framework); TFO (The Future Okavango).

A diversificação dos meios de subsistência em uma comunidade rural do delta do Okavango, Botsuana - Resultados de estudo de base sócioeconômica

Resumo: Devido a uma mistura especial de fatores influenciadores e condições básicas, as estratégias de subsistência na aldeia de Seronga são altamente diversificadas. A localização remota de Seronga no extremo norte do delta do Okavango afasta a população dos centros urbanos e da modernidade. Portanto, a produção agrícola e a criação de gado continuam a ser a principal base de subsistência para a maioria da população. Ao mesmo tempo, as diversas conexões para as cidades maiores, a presença do turismo e a crescente integração do mercado abrem caminho para essa lacuna, transformando desejos, aspirações e reivindicações. Consequentemente, a necessidade de adaptar as estratégias de subsistência para a geração de renda emerge. Neste trabalho combinamos métodos qualitativos e novos dados quantitativos do estudo de base sócio-econômica (SEBS) do "The Future Okavango" (TFO) para realçar a composição das estratégias de subsistência na comunidade de Seronga. Usando o "quadro de subsistencia sustentável" chamamos a atenção para as tendências de transformação, a estratificação sócio-econômica das estratégias de subsistência e as diferenças resultantes da vulnerabilidade e sustentabilidade para as famílias de Seronga.

Palavras-chave: Despesas; economias domésticas; estratificação social; estratégias de subsistência; estudo de base sócio-econômica; modernidade; renda; sustentabilidade; vulnerabilidade.

Received: 15 August 2013 - Accepted: 18 December 2013

\section{Introduction}

The concept of "livelihood" is crucial to the understanding of the on-going discussion on poverty alleviation and rural development in sub-Saharan Africa. It departs from the traditional sectoral approach by conceptualizing poverty in a broader and holistic context that is not only limited to lack of income. The concept also takes into account factors such as lack of access to education and health as well as vulnerability to external shocks (Krantz 2001). The means of securing livelihoods are diversified in most sub-Saharan African countries and could include both natural resource-based and non-natural resource-based livelihood activities. Though agriculture still remains a key sector in the rural economies of sub-Saharan Africa, households' livelihood strategies include a variety of farm and non-farm activities that produce additional income, both in terms of cash and in-kind (Smith et al. 2001).

Specific literature on Botswana and Ngamiland in particular reveals that households' livelihood activities are diversified as an attempt to spread risks and buffer shocks (Kgathi \& Motsholapheko 2011; Motsholapheko 2013). The Okavango people's exposure to risks is explained by their strong reliance on natural resources. The origins of these risks are mainly shocks such as 
animal and human diseases, recurrent droughts and extreme floods (Kgathi et al. 2007). A study on the development of the research strategy in the Okavango Delta for the Okavango Delta Management Plan revealed that there is a gap in knowledge on the dynamics of livelihood strategies in different areas of the Okavango Delta (Ashton et al. 2006). In this paper, we examine livelihood strategies and dynamics of the rural households in Seronga village using the Sustainable Livelihoods Framework (SLF) (DFID 2001, Scoones 1998, Krantz 2002, Chambers and Conways 1992, Scoones 2009)

Despite a strong reliance on the natural resource base, we observe an increasing integration of rural communities of the Okavango Delta into national and international economic structures and, as a consequence, an increasing significance of cash income. This development is seen as one important feature of development and 'modernity' (Beck 2000). In order to consider this transition to a cash-based system, we will investigate how the access to cash income affects rural livelihoods and which consequences and opportunities arise with regard to the sustainability of people's livelihoods.

The specific objectives of the paper are (1) to analyze people's livelihood activities, assets, and diversification strategies, (2) to determine the composition of activities and assets for different income groups, and (3) to investigate the consequences of livelihood diversification with regard to the specific contextual challenges and opportunities. This information will be discussed in the context of resilience and sustainability of household's livelihood strategies.

\section{Background concepts}

Based on Ellis (2000) we understand a livelihood as more than just income.

\section{[...]. [It] "comprizes the assets (natural, physical, human, financial and social capital), the activities, and the access to these (mediated by institutions and social relations) that together determine the living gained by an individual or household."}

Livelihood activities determine the strategies or the ways in which livelihoods are secured and could be natural resource-based or non-natural resource-based. Closely related to the

concept of livelihood is the concept of income, which is defined here in a broader context in terms of both cash and in-kind income. Emanating from this holistic concept of a livelihood, Ellis (1999) defines livelihood diversification as

\section{[...] "the process by which rural families construct a diverse portfolio of activities and social support capabilities in their struggle for survival and in order to improve their standards of living."}

For Sub-Saharan Africa, case studies provide evidence for an increasing diversification of livelihoods in peasant societies, a phenomenon referred to as deagrarianisation (Schnegg 2009, Little et al. 2001, Bryceson 1996, 1999, Reardon 1997). Motives for these developments can be found in risk reduction, population pressure, landholding fragmentation, reaction to crisis or shocks, climatic changes and financial dependencies. Additionally, higher education levels and increasing (global) market integration create new desires and needs (Schnegg 2009, Barrett et al. 2001). The impact and interaction of these drivers and, as a consequence, the characteristics of the diversified livelihoods are different from region to region, household to household, and person to person. This paper supports and extends the empirical knowledge on livelihood composition, providing household-level data on the livelihoods of a peasant society in Ngamiland District, Botswana.

\section{The Sustainable Livelihood Framework (SLF)}

The idea of the "sustainable livelihood" was first introduced by the Brundtland Commission on Environment and Development in 1987 (United Nations 1987), and further developed by the 1992 United Nations Conference on Environment and Development which conceived it as a goal for addressing poverty (Krantz 2001). In addition, the debate on rural development by scholars such as Chambers and Conway (1992), Carney (1998), Scoones (1998), and Ellis (2000) further developed this concept.

The paper follows the Sustainable Livelihoods Framework (SLF) (DFID 2001, Scoones 1998, Krantz 2002, Chambers and Conways 1992, Scoones 2009, Hamilton-Peach and Townsley, 2004) as a methodological guideline for the analysis and for the integration of different dimensions of livelihood diversification in Seronga. The framework is a people-centered and holistic tool for analyzing the various factors and processes which affect the ability of the poor to obtain a living (DFID 2001).

The investigation of livelihoods in the SLF is structured by mainly four elements that are linked in several ways (Fig. 1): (1) livelihood activities, (2) livelihood resources in form of five livelihood assets (human, social, natural, financial, and physical capital), (3) risks and vulnerabilities (vulnerability context) and (4) transforming structures and mediating processes (Ellis 2000, Kgathi et al. 2007).

SLF scholars have recently argued to include a sixth capital asset into the SLF, which is referred to as personal capital and which reveals the internal motivations and willingness of people to act and promote change (Hamilton-Peach and Townsley 2004). Furthermore, some scholars include political capital into the framework, in order to make the SLF more suited as practical approach comprising endogenous and exogenous power relations that "people can draw on [...] in order to pursue livelihood options" (Baumann 2000). However, due to data restrictions, we will limit our analysis to the core five capital assets of human, social, natural, financial, and physical capital.

1. Human capital includes education, skills, knowledge, health of the household members as well as household size and composition. These factors are decisive for the household's capacity to work and to adapt to changing circumstances.

2. Social capital is composed of networks or connectivity to other households (at other locations), group building processes, and common knowledge of rules and norms. Trust, reciprocity and exchange relations are relevant for creating a favorable social and economic environment. Social relations shape the institutional foundation in the management of natural resources and form a safety net for the people. In addition, they create by themselves a feeling of well-being.

3. Natural capital covers the natural resource base, which provides goods, services and functions. It is one of the material foundations of people's livelihoods. Natural capital is important for the people's health (e.g. water quality) 


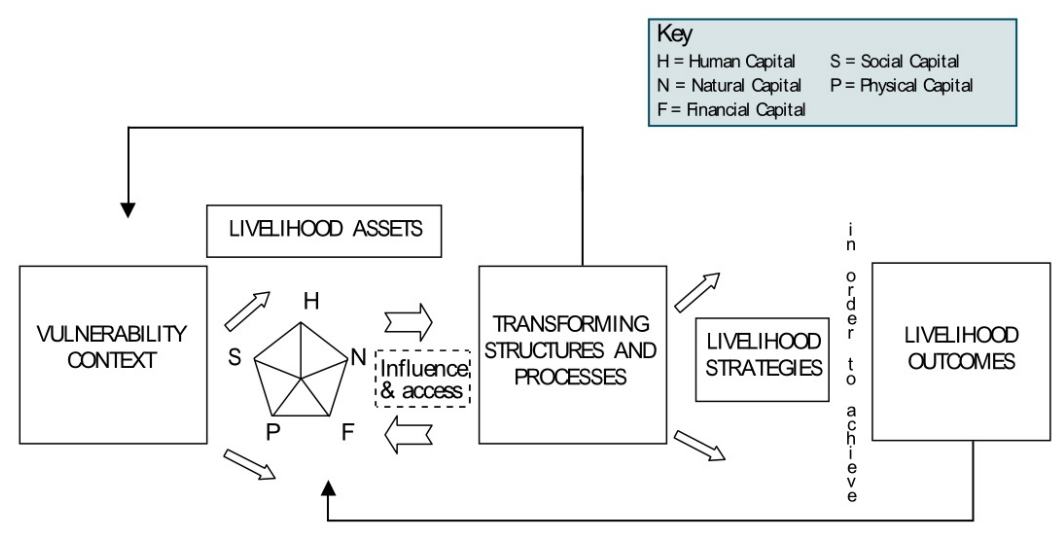

Fig. 1 Sustainable Livelihood Framework (DFID 2001).

while it can become a hazard in times of natural disasters.

4. Financial capital considers not only stocks, but also flows of financial capital. As a result of increasing market integration this form of capital is one of the main drivers of social change. Financial capital also includes disposable assets such as livestock, which constitute an important financial capital stock in rural areas like those of Ngamiland in Botswana.

5. Physical capital includes infrastructure, shelter, and means of production. Often it is a good indicator for a specific configuration of livelihood strategies. Technological change is an important driver for livelihood transformation (DFID 2001, HamiltonPeach \& Townsley, 2004).

Access to livelihood assets and activities is mediated by the vulnerability context and transforming structures and processes. The vulnerability context includes shocks (epidemics, natural disasters etc.), seasonality (labour opportunities, production cycles etc.) and critical trends, which may be of demographic, economic, political and technological origin (Serrat 2008, DFID 2001, Domptail et al. 2013). The structures that transform livelihood capital assets and activities include public and private sector organizations, which introduce and implement policies and laws that affect livelihoods. Processes include formal and informal institutions (rules, laws, policies and norms) and social relations (gender, ethnicity and religion). They affect the ways in which people combine and use their capital assets to achieve their livelihood goals (Ellis 2000, Serrat 2008, DFID 2001). Finally, livelihood outcomes may include a higher living standard, reduced vulnerability, an increase in food security, district of Botswana, on the banks of the eastern side of the Okavango Panhandle. Seronga (and its 10 cattle posts) had a population of 2,674 in 2011 (SEBS) and it is one of the major settlements in the region Ngamiland West, which is home to about $3 \%$ of Botswana's total population (Botswana Central Statistics Office, 2011). The main village, surrounding cattle posts and agricultural plots, cover an area of roughly $1,473 \mathrm{~km} 2$. Seronga's climate is semi-arid and characterized by an average rainfall of $500 \mathrm{~mm}$. There is a high climatic variability, which leads to a very unsteady growing season and thus to an unreliable basis for agricultural production and a high vulnerability to climate change. Fertile soils are limited to former flood plains, which have emerged as a result of past changes in the course of the Okavango River. These areas are currently almost fully under use. Surrounding this pocket of former flood plains, Kalahari sands make any largescale extension of rain-fed agriculture little attractive. Thus, the area is marginal for agricultural use. The open woodland savannah of Mopane and Acacia stretches on Kalahari sandy soils and provides natural resources as well as grazing grounds in the wet season for people and livestock. Wetlands provide access to specific wetland foods and handicraft material such as lily roots (tswii) and papyrus. They also ensure grazing areas and water (albeit of poor quality) for livestock in the dry season. A sandy and graveled road links the community to the outside world - further downstream the Delta to the east and via the ferry across the Panhandle to bigger cities in Botswana and Namibia to the west. Shakawe, another urban village, administrative center (2011 the population was around 6,693 inhabitants) and the closest place with shopping facilities, is located about 100 kilometers away from Seronga. The distance from Shakawe to the Ngamiland administrative centre of Maun is $490 \mathrm{~km}$.

Thus, remoteness attributes especially to the spatial distance from the urban hubs of modernity and consumerism. Moreover, Seronga's position at the Okavango Delta, one of Africa's largest and most beautiful and protected wetlands, implies two things for people's lifestyles: On the one hand, it facilitates livelihoods that are shaped by a tradition of intensive natural resource use. On the other hand, it turns the village into a transit zone for tourists, who mostly arrive by a speedboat connection from 
Sepopa or by plane, which is both exclusively dedicated to them and not to the local people. Besides this infrastructural presence of modernity, tourists also transfer new ideas, tastes, and desires to the community contributing to a change in life prospects and objectives. Furthermore, the village comprises a high density of governmental institutions (a clinic, two schools, the land board, the police, the wildlife department, etc.), promising support, employment, security, and more generally the presence of the government. Looking at these attributes of life, livelihood strategies of Seronga's population are not straightforward and shaped by both: (1) remoteness, poor connectivity, and a subsistent use of natural resources, and (2) traits of modernity induced i.a. by tourism, the government, and the media.

According to Statistics Botswana (2011), the proportion of people living below the poverty line was $47.3 \%$ in Ngamiland West in 2009/10 as compared to a national Fig. of $20.3 \%$, suggesting that the region has a high incidence of income poverty. This high incidence of poverty in Ngamiland district suggests that the wealth of the country has not sufficiently trickled down to the poor as Botswana is an upper middle income country with a gross national income per capita of US\$ 6,890 in 2010, which is among the highest in sub-Saharan Africa (World Bank 2012).

\section{Data collection and analysis}

Table 1 gives an overview of data sources and the methods of data collection. In 2011, we conducted a structured household survey which will be referred to as Socio-economic Baseline Survey (SEBS). The SEBS contains questions on households' socio-demographic attributes, household consumption and living situation, household production activities, income sources, and expenditure. After listing all existing households in the village and its surrounding cattle posts, a simple random sample of 334 households was drawn using statistical software. Due to refusals or non-completion of interviews, data from 326 households covering 1026 individuals in the greater Seronga area were included in the analysis. This survey is the main data source for this paper. When appropriate, a study conducted by Kgathi and Motsholapheko in 2003 in five communities of the upper and lower Okavango Delta, including Seronga, complements SEBS data. They applied a mixture of methods such as formal questionnaire interviews, informal interviews and focus group discussions (Kgathi \& Motsholapheko 2011). In addition, results from different ethnographic data collection methods are integrated in this study. In qualitative research it is common to work with considerably smaller sample sizes based on non-probability sampling to gain a more interpretive and in-depth understanding of the research subjects in their specific socio-cultural contexts (Bernard 2011). Hence, those data provide background information to embed and understand insights gained from SEBS data. Besides participant observations and informal discussions, 28 semi-structured individual interviews were conducted. 18 informants were

Table 1: Illustration of data souorces.

\begin{tabular}{|c|c|c|c|c|c|c|c|}
\hline $\begin{array}{l}\text { Data } \\
\text { source }\end{array}$ & SEBS & $\begin{array}{c}\text { Kgathi and } \\
\text { Motsholapheko }\end{array}$ & Herold & Herold & Herold & Herold & Domptail \\
\hline Institution & TFO & ORI & TFO & TFO & TFO & TFO & TFO \\
\hline Year & 2011 & $2011(2003)$ & 2011 & 2011 & 2011 & 2011 & 2013 \\
\hline $\begin{array}{l}\text { Sample } \\
\text { size }\end{array}$ & 326 households & 129 households & 10 informants & 18 informants & 6 households & 20 households & 32 informants \\
\hline $\begin{array}{l}\text { Sampling } \\
\text { method }\end{array}$ & $\begin{array}{l}\text { Random } \\
\text { sampling after } \\
\text { household listing }\end{array}$ & $\begin{array}{l}\text { Two-stage } \\
\text { stratified random } \\
\text { sampling }\end{array}$ & $\begin{array}{l}\text { Opportunity and } \\
\text { stratified } \\
\text { sampling }\end{array}$ & $\begin{array}{l}\text { Opportunity and } \\
\text { stratified } \\
\text { sampling }\end{array}$ & $\begin{array}{l}\text { Opportunity and } \\
\text { stratified } \\
\text { sampling }\end{array}$ & $\begin{array}{l}\text { Opportunity and } \\
\text { stratified } \\
\text { sampling }\end{array}$ & $\begin{array}{l}\text { Stakeholder } \\
\text { analysis }\end{array}$ \\
\hline Location & $\begin{array}{l}\text { Seronga and } \\
\text { surrounding } \\
\text { cattle posts }\end{array}$ & $\begin{array}{l}\text { Shorobe, } \\
\text { Etsha 6, } \\
\text { Seronga, } \\
\text { Gudigwa, } \\
\text { Sehitwa }\end{array}$ & Seronga & Seronga & Seronga & Seronga & $\begin{array}{l}\text { Seronga, Maun, } \\
\text { Gabarone }\end{array}$ \\
\hline Method & $\begin{array}{l}\text { Quantitative } \\
\text { household } \\
\text { survey }\end{array}$ & $\begin{array}{l}\text { Quantitative } \\
\text { household } \\
\text { survey, informal } \\
\text { interviews focus } \\
\text { groups }\end{array}$ & $\begin{array}{l}\text { Semi-structured } \\
\text { interviews }\end{array}$ & $\begin{array}{l}\text { Semi-structured } \\
\text { interviews }\end{array}$ & $\begin{array}{l}\text { Semi-structured } \\
\text { interviews }\end{array}$ & $\begin{array}{l}\text { Household } \\
\text { inventories }\end{array}$ & $\begin{array}{l}\text { Qualitative } \\
\text { interviews }\end{array}$ \\
\hline Scope & $\begin{array}{l}\text { Demography, } \\
\text { consumption, } \\
\text { assets, } \\
\text { production, farm } \\
\text { management, } \\
\text { income sources, } \\
\text { expenditure }\end{array}$ & $\begin{array}{l}\text { Analysis of } \\
\text { livelihood } \\
\text { diversification } \\
\text { according to type } \\
\text { and location of } \\
\text { households }\end{array}$ & $\begin{array}{l}\text { Consumption } \\
\text { incentives }\end{array}$ & $\begin{array}{l}\text { Livelihoods, } \\
\text { consumption }\end{array}$ & $\begin{array}{l}\text { Income, } \\
\text { expenditure }\end{array}$ & $\begin{array}{l}\text { Current status of } \\
\text { and dynamic } \\
\text { behind } \\
\text { households } \\
\text { material } \\
\text { equipment }\end{array}$ & $\begin{array}{l}\text { Key drivers of } \\
\text { land and } \\
\text { resource use }\end{array}$ \\
\hline
\end{tabular}


asked mainly about general aspects of livelihoods and consumption, whereas 10 interviews addressed consumption incentives. At the household level, an extensive semi-structured questionnaire on income and expenditure was conducted within 6 households. Additionally, household inventories (Roberts 1951, Hahn et al. 2008) were collected within 20 households, in which information about the origin of a good, reason of acquisition and source of cash was gathered for around 150 household goods. Household inventories give an in depth impression of the life realities of people and deliver an insight into material manifestations of social stratification and (changing) consumption patterns. They also indicate changes in people's desires and achievements and give an idea of the current status of market integration. Further qualitative data was collected in 2013 among 32 stakeholders at four governance levels (basin, national, district and local) about key drivers for the future land and resource use in Seronga.

Descriptive statistics are the main quantitative tools of this paper. We follow the SLF definitions in the selection of information on the four framework elements. Livelihoods assets are the object of both qualitative and quantitative analysis. For information synthesis we constructed indices for the different livelihood assets. The heuristic followed is described in the corresponding section. An estimation of annual disposable household cash income is based on SEBS data and includes household's yearly income from regular salary, private business activities, government pensions and grants, remittances (cash and in-kind) as well as retail and exchange of subsistence agricultural production, natural resources and livestock.

\section{Livelihood Activities}

According to the SEBS, the main livelihood activities in Seronga include arable agriculture, formal employment, livestock farming, community-based tourism, veld products collection and fishing. In recent years, social welfare programs have increasingly become important safety nets in Seronga as it is the case in other parts of Ngamiland.

According to the SEBS, $59 \%$ of all households practice cropping and/or gardening activities. Most of those who practice traditional farming hardly use fertilizers or manure while the use of improved seeds is common. Concerning the staple food of Seronga's population, SEBS shows that $81 \%$ of the households that practice cropping grow millet, $74 \%$ sorghum, and $63 \%$ beans. Important seasonal products are vegetables like beans $(80 \%$ of the households that practice cropping) and pumpkin (46\%), as well as fruits and nuts like watermelon $(88 \%)$, groundnuts $(61 \%)$ and papaya $(23 \%)$. For a more analysis of food consumption, see Eigner (2012). The mean crop yields in 2011 were $331 \mathrm{~kg}$ of millet, $351 \mathrm{~kg}$ of sorghum, and $165 \mathrm{~kg}$ of maize. $18 \%$ of agriculturally active households sell, exchange, or donate part of their harvest but only few said they produced crops with the intention of selling.

The main cash income crops, vegetables or fruits are millet, beans and groundnuts. However, the marketed agricultural production makes up less than $1 \%$ of disposable household income. Agricultural production can therefore be classified to be rather non-commercial. Reasons are ecological production limits (i.e. soil fertility, spatial and temporal variability of rainfall), constraints in means of production, a lack in farm labour and Seronga's poor market integration regarding agricultural products. However, the government has launched incentives to increase efficiency amongst poor farmers (Accelerated Rainfed Arable Program, ARAP) and to establish distribution channels (Botswana Agricultural Marketing Board, Botswana Meat Commission). The income from ARAP is an important cash factor for household's economies: The six households who participated in the ethnographic survey received an average ARAP payment of US\$161 per year (ranging from US\$51 - US\$360, depending on field size). These payments (up to $10 \%$ of a household's income) are an important and stable source of cash income especially for households without income from formal employment or private business.

In most parts of Ngamiland, livestock farming used to be the most important livelihood activity before the culling of cattle in 1995/96 because of the contagious bovine pleuro-pneumonia (CBPP) (Bendsen 2002). Although livestock farming is now significantly less important, it is rapidly recovering. Qualitative interviews hint that livestock ownership remains an important and desired life objective, even for younger people. However, alike the rest of Botswana, distribution of cattle ownership is skewed in Seronga.

With regard to the sum of cash incomes, in SEBS salaries make up the largest share of around $64 \%$, followed by private business earnings (20\%), pensions (7\%), and livestock sales (6\%). Only $28 \%$ of the economically active population (all individuals aged 18-64) receives either a regular salary or revenues from a private business. $60 \%$ of all households sustain their livelihoods without any form of formal or self- employment. 88 of 118 eligible individual in SEBS above the age of 65 received the standard old age pension (US\$31 per month) from the Botswana Ministry of Local Government. Another 33 of 1026 individuals included in the SEBS obtained a cash or in kind state transfer for the disabled, orphans, or poor citizens. Overall, $40 \%$ of SEBS households do not receive cash income from formal employment, private business or pensions. An option for households without regular cash income to earn money is doing casual work or Ipelegeng, short-term employment by the government (Ministry of Local Government 2011). These results are in line with the findings of Kgathi and Motsholapheko (2011) for their wider research area. They find that formal employment accounts for $45.7 \%$ of cash incomes, followed by other income sources $(13.3 \%)$, government assistance $(9.3 \%)$ and livestock farming $(8.7 \%)$.

\section{Livelihood Assets}

As a core element of the SLF, we will assess livelihood resources, proposing a more detailed analysis of the five livelihood assets human, social, natural, financial and physical capital for the entire population of Seronga. We do not attempt to sharply separate all SLF components in our analysis, because doing so seems inappropriate and impossible at times. Consequently, the respective capitals will overlap with livelihood activities and outcomes.

\section{Human capital}

Seronga's housholds show interesting composition features. The population is generally young with $55 \%$ of all individuals being between 6 and 36 years of age. We find a gender imbalance towards females, especially in adult age. Also, $50 \%$ of adults are single, only one quarter is married (either traditionally or with certificate) and $8 \%$ widowed. These findings could be the result of 
employment and education related migration, in combination with the impact of the HIV/AIDS pandemic. The male migrating population is especially more vulnerable to HIV/AIDS infection as a result of being away from the community's social control. Kgathi and Motsholapheko (2011) estimate the percentage of infected households at $33 \%-53 \%$ in Ngamiland West. This number is substantially higher than the national HIV prevalence rate (among adults aged 15 to 49 ) of $23 \%$ (UNAIDS n.y.). The Government attempts to improve the physical and social health of the community with measures such as free provision of anti-retroviral medication and campaigns for acceptance of HIV infected people. Nevertheless, HIV is still associated with an important social stigma and continues to have a huge negative and inter-generational effect on human capital. Another serious health risks are tuberculosis and Malaria. Wall-spraying with residual insecticides (DDT) and awareness campaigns are aimed at controlling the spreading of this disease.

Table 2 shows that among adults (age 18 and above), education levels are generally very low. Women appear to have lower access to education, especially to tertiary education. The generally poor level of education among adults is supported by Kgathi and Motsholapheko (2011), who found that $30 \%$ of the informants had not completed primary level education. Poor education strongly contributes to the fact that most adults $(63 \%)$ mention subsistence farming activities as their main occupation. According to World Bank (2013), Botswana had a total net enrolment ratio in primary and secondary schools of $86 \%$ and $61 \%$, respectively, in 2008 . In the SEBS, we found that only $5 \%$ of children between 6 and 17 are not or were never enrolled in primary and/or secondary schools. Overall, the young generation of Seronga has a reasonably good level of education, considering the remoteness of the village. This indicates a high and successful enforcement of Botswana's education system even in this rural area. Despite having a better-educated younger generation, there seems to be few opportunities to make use of this knowledge. While some of the educated people migrate to the urban centers for (post-)secondary education or cash earning purposes, this movement is usually temporary. Qualitative interviews and informal conversation with young

Table 2: Education levels by gender among adult population.

\begin{tabular}{lccc}
\hline $\begin{array}{l}\text { Highest level of } \\
\text { education } \\
\text { attained (age 18 } \\
\text { and above) }\end{array}$ & Male & Fender & \\
\cline { 2 - 3 } $\begin{array}{l}\text { No formal } \\
\text { education }\end{array}$ & $39 \%$ & $46 \%$ & Total \\
\hline $\begin{array}{l}\text { Primary school } \\
\text { Junior secondary }\end{array}$ & $20 \%$ & $18 \%$ & $43 \%$ \\
school & $19 \%$ & $24 \%$ & $19 \%$ \\
$\begin{array}{l}\text { Senior secondary } \\
\text { school }\end{array}$ & $9 \%$ & $9 \%$ & $22 \%$ \\
Tertiary education & $13 \%$ & $2 \%$ & $9 \%$ \\
\hline
\end{tabular}

people about their life objectives showed that employment opportunities are limited, and the cost of living in the urban centers is high. In contrast, pull factors of Seronga such as low monetary pressure, family ties, easy access to natural resources and land, calmness, security and beauty are highly valued. This ambivalence makes many young people continuously look for employment opportunities in towns, while keeping in mind the option of returning. In this regard, the village and its specific lifestyle function as a backup plan and as unemployment insurance.

\section{Social capital}

Important factors that shape social capital are groups (vertical and horizontal) and relations between these groups (power, safety, support etc.) as well as connections and networks, which open up working or living opportunities in other villages or cities. In Seronga, one factor of grouping is ethnicity, which in the SEBS was operationalized as 'mother tongue'. While the two main ethnic groups of Bayei (mother tongue Seyei, $56 \%$ of the population) and Hambukushu (mother tongue Sembukushu, 24\%), live amongst each other in the core village, many of the minority Basarwa people (mother tongue Sesarwa, 5\%) live in cattle posts or small settlements outside Seronga under poorer conditions. They commonly work as employees or servants for richer households in the village. They are exposed to prejudices and play - if at all - a marginal role in the politics of Seronga. The power relations of Bayei and Hambukushu seem to be equal. Cross marriages are common while clan membership is inherited matrilineally.

A second grouping factor in Seronga is religion. The SEBS shows that $55 \%$ of the households are Christian, $2.5 \%$ have a traditional religion, and $41 \%$ have no religion. Church membership is highly fragmented. In total we counted more than 30 different churches in the Seronga area, with member numbers ranging from less than 20 to hundreds of believers. The importance of religion is reflected by the financial contributions of even poor members to their respective churches.

With regard to economic grouping, Kgathi and Motsholapheko (2011) found that only $39 \%$ of the households would seek help from close relatives, friends, or neighbors when faced with financial constraints though access to formal financial services is limited. This finding speaks for a fragmented society where people mostly rely on the household and the (core) family. Exceptions are extreme (financial) situations like funerals or weddings, where these groups are expanded.

Social networks partly mitigate the high transaction costs of looking for employment. Relatives or friends permanently living in Shakawe, Gumare, Maun or other cities help finding jobs and reduce the costs of temporal visits. Nevertheless, the SEBS shows that only $19 \%$ of the households received remittances in form of money or food. In contrast, $55 \%$ of the households paid remittances (mostly money and in-kind) to family members living in Seronga or elsewhere.

Our observations further reveal that life concepts are generally rather individualistic and headed towards the future with a focus on the/an own family 
and an own compound or a life in an urban area. Consequently, despite Seronga's rural location, households exhibit some specific human and social properties of modernity mainly because of their level of education, their individual freedom, the high importance of the individual, functioning political institutions, and limited non-monetary exchanges.

\section{Natural capital}

The natural environment of Seronga allows a diverse use of natural resources. The access to both Delta and Savannah is key to people's livelihoods and provides a wide range of natural resources: wood for construction, stones/soil/clay and thatch grass for building and maintaining housing, fruits, fish and nuts. All of these resources are used by more than $80 \%$ of households, respectively. Surprisingly, only $57 \%$ of the households indicate to use reeds from the delta, $49 \%$ state to catch fish, and only $37 \%$ use game. More than $91 \%$ of households use firewood as the main source of energy for cooking, heating and lighting. Especially during rainy season, paraffin and candles are frequently used. Only $25 \%$ of the households mention 'modern' energy sources such as gas, electricity, solar panels or diesel as their main source of energy. Residential and cropping land can be freely obtained by all citizens from the Botswana Land Board, upon application. According to the SEBS, $77 \%$ of the households are allocated at least one field (few of them more than one).

\section{Financial capital}

In rural societies, natural capital is closely linked to financial capital. This holds true especially for livestock due to its easily disposable character and multidimensional values (Falk 2008). Livestock, especially cattle, serves as a potential source of nutrition, means of transport, and production (e.g. plough actuator). It is a source of social status and is used as savings accounts or even directly exchanged. It also plays an important role in the social relations of the community, for instance by its use as bride prices (Bendsen 2002)

In the SEBS, $50 \%$ of households indicated to own livestock with a mean of 17 livestock units per household and $42 \%$ owned cattle. In terms of financial value, selling and exchanging livestock is one of the means to generate cash income. The quantities of sold, exchanges and donated livestock make up about $6 \%$ of households total disposable cash income. Despite this rather low contribution to cash income livestock is perceived to be very important. We asked 26 households how they would spend a gift of US $\$ 12,000$ and 22 of them stated they would purchase (more) cattle.

Slaughtering for own consumption is rare, whereas occasional selling of livestock to one of the two local butcheries or to Botswana Meat Commission is the most common practice. Reported prices range from US\$173 to US\$433 per head of cattle. In general, selling an animal is mostly done to meet the expenses of a particular occasion (i.e. funeral, wedding) or a desired asset (e.g. car or generator) and people are very careful when it comes to making decisions regarding livestock.

According to the Botswana Core Welfare Indicators Survey 2009/10, disposable household income (includes in-kind income and excludes savings or stocks) for rural areas in Botswana was of US $\$ 3,795$ per year (author's own calculations based on Central Statistics Office 2011). Based on SEBS data we calculated a lower gross average disposable income of US\$2,911 per year and household for the Seronga area. Salaries are the most important source of cash income for SEBS households, but only one third of all households have at least one member receiving a regular salary. Within this group, roughly half of the people are employed in the public sector $(38 \%)$, where wages are generally highest (on average US\$729 per month), or in the lower paid extension of the public sector $(6 \%)$. The other half works in the tourism industry $(38 \%)$, or in the private sector $(10 \%)$, where wages are significantly lower (on average US $\$ 240$ per month). For those households without formal employment (68\% of sample), average disposable cash income drops to US\$1049 per year. Regarding private businesses, the second largest share of cash incomes, $12 \%$ of households indicated to have at least one business. The food and beverage sector - mainly selling of traditional beer and fat cakes accounts for $30 \%$ of businesses, followed by services and crafts $(28 \%)$, retail of products (i.e. street vendors), and selling of natural resources including fish $(21 \%$ and $20 \%$ respectively). Success amongst business owners seems diverse as we found a mean income of US\$370 compared to a median of US\$14 per month. Only $63 \%$ of these households mainly rely on their business income. In $37 \%$ of households with business activity additional salaries are being earned.

The use of financial services in Seronga is, however, limited. Roughly one third of all households within SEBS had a bank account and only one quarter of all households saved income, either at formal institutions (bank or post office, $80 \%)$, or at home $(20 \%)$.

\section{Physical capital}

Public infrastructure as an important aspect of physical capital is poorly developed in Seronga and its surrounding cattle posts.

The community is connected to the rest of the country by a poorly maintained sandy road. There is no bridge over the Panhandle so a ferry links both sides of the River. Due to frequent breakdowns, shortages of fuel and limited transporting capacity, crossing of the river becomes a bottleneck. Alternative travelling means are scarce and the land strip for aerial transport is in a degrading state, making landing hazardous. Seronga is only equipped with two small private fuel points but no official filling station. Diesel, petrol and gas are bought in Shakawe where shortages are common.

Seronga has a well with an engine pump and a water pipeline system, which distributes water to private and public water taps. Nevertheless, the state of the pipelines and storage facilities is poor resulting in low water quality and frequent supply cuts. The situation is even more severe outside the core village. At cattle posts, there are no pipeline systems and people collect water at public water points. In such cases, public water tanks are filled by water trucks once a week. The quantity of water provided is usually limited and water supply is insecure especially during the rainy season.

Two diesel generators were installed in Seronga in 2011, which was facilitated by financial support obtained from international development funds. The installation of electricity lines progresses steadily even though getting connected to the electricity network implies significant private transaction costs. Central Seronga is covered by two rather unstable mobile networks. There is a post office in Seronga. Mail is usually delivered once a week, but less frequently during the rainy season. A supermarket offers a limited range of products and financial services. 
Prices are higher than in Shakawe or Maun and the provision of banking services is unreliable due to unstable telephone connections.

In contrast to the poor public infrastructures, privately owned assets of households in Seronga constitute a welldeveloped physical capital base. On average, households have 2.5 buildings on their compound, which seems reasonable with regard to the average household size. Houses (If there was more than one house, we only assessed the material of the house of the head of household) are mostly made from wooden sticks, filled up with mud and cow-dung $(54 \%)$ or bricks made out of termite hill soil or cement (31\%), covered with thatched grass from the river $(71 \%)$ or corrugated iron sheets $(28 \%)$.

Almost three quarters of households have access to public $(38 \%)$ or private $(32 \%)$ water taps or water tanks. The remaining quarter of households uses water from the River $(27 \%)$ as main source of drinking water. Access to safe water is still a challenge mainly at the cattle posts surrounding Seronga, which are not connected to the local water line system.

Nearly all households own modern mattresses (95\%) and plastic chairs (93\%). Three quarters of all households also own at least one and on average 1.7 cell phones. Many households own a radio and a stove. More sophisticated entertainment electronics and motorized means of transport were hardly mentioned. The ethnographic household inventories confirm this picture. After choosing 48 indicator goods out of the total list of households' possessions, we find a strong heterogeneity in the assets endowment among the 20 interviewed households. We grouped all households according to the percentage of possessed goods: Group 1 are sparsely equipped households, group 2 possess a number of assets close to the average of the whole sample, and group 3 are well-equipped households. All households owned plates, cups, at least one western mattress and bed, chairs and at least one cell phone. Furthermore, nearly all households, including the well-equipped ones, had a 'traditional' mortar and pestle called kika and motshe, respectively, used for grinding the millet. Surprisingly, even the sparsely equipped households reported having items like toiletry, especially body lotions. Besides these similarities, differences of these groups can be identified on the basis of their physical endowments: Well-equipped households e.g. more frequently possess modern food items like rice, sugar, coffee, tea, tomato sauce or cooking oil whereas nearly all sparsely equipped households do not possess them. Additionally, sparsely equipped households do not own electronic devices such as TVs, stoves, fridges, and generators or furniture like wall-units or headboards locally perceived as 'modern'. Furthermore, cattle and ploughs are scarce in sparsely equipped households. Qualitative interviews showed that houses, cars, cattle, and furniture were the most valued signs of wealth

The remoteness of Seronga from commodity markets is thus not reflected in people's physical endowments. The material culture is evidence for wellfunctioning connections to the urban centers where people buy new consumer goods to equip and develop their homes. Here, we find evidence for the importance of cash income, which is an essential prerequisite for the establishment of this type of physical capital base.

\section{Access to assets by income groups}

The assessment of livelihood assets indicated a heterogeneous composition of capital endowments in our sample. In this section we analyze the stratification of households using descriptive statistics and graphical analysis.

In a first step, we identified indicators for each capital category. Our indicator for financial capital is the average monthly disposable household cash income in 2011. Social capital and in particular the household's integration in networks inside and outside of Seronga is represented by the absolute amount of remittances the household receives and/or pays per month. Since we consider education as one of the main driving forces for development, we chose the highest level of education attained among adult household members as an indicator for human capital. For natural and

Table 3: List and range of indicators included in the capital asset pentagon indices.

\begin{tabular}{|c|c|c|c|c|c|}
\hline Type of capital & Natural capital & Physical capital & Social capital & Human capital & Financial capital \\
\hline Description of Index & $\begin{array}{l}\text { Total number of } \\
\text { natural resources } \\
\text { used per household }\end{array}$ & $\begin{array}{l}\text { Total number of } \\
\text { physical assets per } \\
\text { household }\end{array}$ & $\begin{array}{l}\text { Sum of remittances } \\
\text { the household } \\
\text { receives and/or pays } \\
\text { per month (in US\$) }\end{array}$ & $\begin{array}{l}\text { Highest level of } \\
\text { education attained } \\
\text { among adult } \\
\text { household members }\end{array}$ & $\begin{array}{l}\text { Total disposable } \\
\text { household cash } \\
\text { income per month (in } \\
\text { US\$) }\end{array}$ \\
\hline $\begin{array}{l}\text { Dummy variables, } \\
\text { categories, or } \\
\text { indicator variables }\end{array}$ & $\begin{array}{l}\text { Fish, Roots, Fruits, } \\
\text { Nuts, Game, Worms, } \\
\text { larvae, caterpillars, } \\
\text { Medical plants, } \\
\text { Stones, soil, clay, } \\
\text { Wood for construction, } \\
\text { Grass, Reeds, Timber, } \\
\text { Firewood, Agricultural } \\
\text { production }\end{array}$ & $\begin{array}{l}\text { Radio, Television, } \\
\text { Phone, Mobile phone, } \\
\text { Personal computer, } \\
\text { Camera, Hi-fi set, } \\
\text { Satellite dish, } \\
\text { Refrigerator, Stove, } \\
\text { Mattress, Chairs, } \\
\text { Donkey cart, Bicycle, } \\
\text { Motorcycle, Car, } \\
\text { Bakkie, Truck, Boat, } \\
\text { Modern housing }\end{array}$ & $\begin{array}{l}\text { Monetary and in-kind } \\
\text { equivalent value of } \\
\text { remittances paid and } \\
\text { received per month }\end{array}$ & $\begin{array}{l}\text { (0) No formal } \\
\text { education, (1) } \\
\text { Finished primary } \\
\text { school, (2) Finished } \\
\text { junior secondary } \\
\text { school (grade 10), (3) } \\
\text { Finished senior } \\
\text { secondary school } \\
\text { (grade 12), (4) Further } \\
\text { education (college, } \\
\text { university) }\end{array}$ & $\begin{array}{l}\text { Income from regular } \\
\text { salary, private } \\
\text { business, pensions, } \\
\text { remittances, } \\
\text { retail/exchange/donati } \\
\text { on of natural } \\
\text { resources, agricultural } \\
\text { production and } \\
\text { livestock }\end{array}$ \\
\hline Value range & $0-14$ & $0-21$ & $0-100$ & $0-4$ & $0-1300$ \\
\hline
\end{tabular}




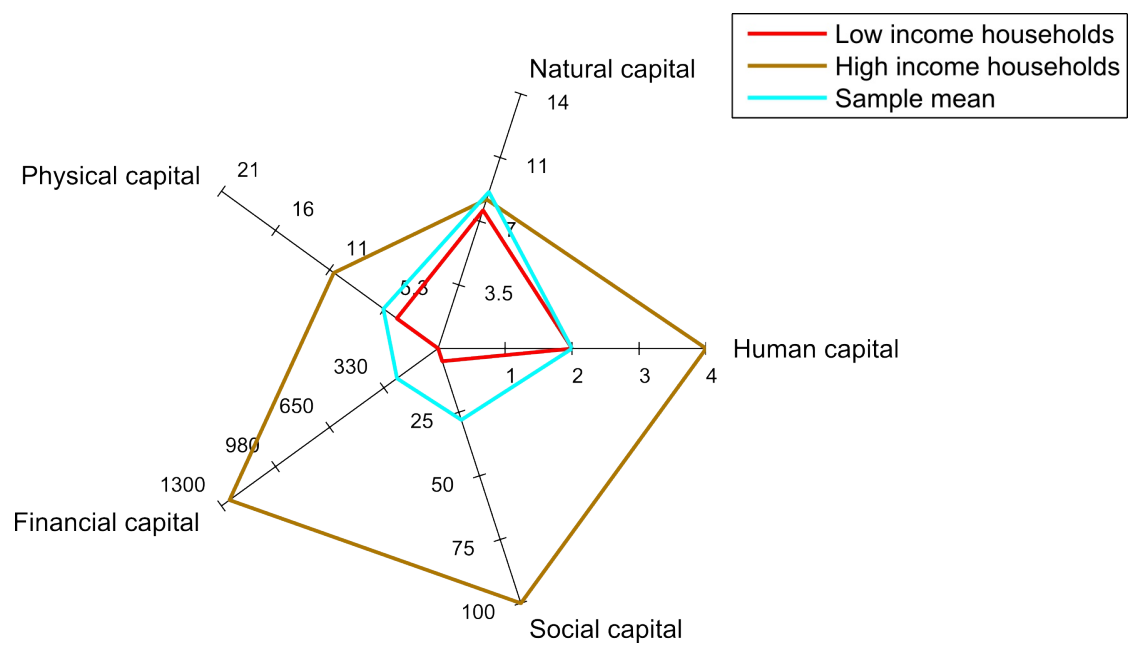

Fig. 2: Pentagon of livelihood dimensions showing the average endowment of financial, physical, natural, social, and the median endowment of financial capital for households of different income groups (lowest percentile, highest percentile) and the entire sample.

physical capital, we calculate indices consisting of the total of dummy variables for possessing different assets. In order to account for the household's endowment with natural capital, we calculated the sum of types of natural resources used by a household (maximum 13) and included whether a household practiced rain-fed cultivation. The index for the household's physical capital includes different types of equipment, means of production and transport, as well as ownership of modern housing (houses made of cement bricks and corrugated iron sheets).

Table 3 illustrates the composition of our indices.

In a second step we take a closer look at the capital endowments of specific income groups of the SEBS population. Due to data inconsistencies for income calculation, we can only include 296 of the total 326 households in this analysis. We focus on the low-income and highincome percentiles in terms of disposable household cash income and compare it with the average of the overall sample. Low-income households ( $\mathrm{n}=55)$ have a monthly disposable cash income of 0US\$, as compared to average households $(\mathrm{N}=296)$ with 246US\$ and high-income households $(\mathrm{n}=31)$ with $1,251 \mathrm{US} \$$. The pentagon in Fig. 2 illustrates the average and median indicator values of our capital asset indices for different income groups and the sample mean. The axis for financial capital represents the disposable household cash income, which is our indicator for this capital category and simultaneously the criterion for the different wealth groups. We find that high-income households have the highest endowments in social (average monthly remittance transfers of US\$100), human (median education level is further education) and physical capital (on average 10 out of 21 assets). In contrast, low-income households have a considerably lower human capital base (finished junior secondary school (grade 10)), lower social capital (average monthly remittance transfers of US\$5) and less physical capital (on average 4 out of 21 assets). Compared to the average household, low-income households are slightly less wellendowed for human (median education level is finished junior secondary school) and physical capital (on average 5 out of 21 assets). The average household is, however, better off regarding social capital (average monthly remittance transfers of US\$28). Interestingly, low and high-income households make use of a similar range of natural resources (on average 8 out of 14 resources), as well as the sample mean ( 9 out of 14 resources). This indicates that access to natural resources is not restricted to specific income groups.

\section{Diversification of livelihoods and livelihood outcomes}

The significant difference in capital endowments between low-income and high-income groups is reflected in the composition of livelihood activities of the respective households (Fig. 3). Highincome households make use of a wide range of livelihood activities, including cash earning activities. Only $29 \%$ of these households are agriculturally active whereas $87 \%$ earn at least one salary, $26 \%$ run at least one private business and $6 \%$ receive at least one government pension. Low-income households mainly rely on their subsistence agricultural production $(64 \%)$, without retail. The lower level of education among lowincome households may be one key factor for this finding, since most employment opportunities in the public and private sector require tertiary education. $70 \%$ of low-income household heads' education level does not go beyond finishing of primary education. Livestock keeping is more frequently practiced by highincome households ( $52 \%$ as compared to $27 \%$ of low income households) with much higher numbers of cattle (on average 9.4 versus 1.9 heads) and poultry such as chicken (on average 1.4 versus 6.2). This highlights the multidimensional character of cattle ownership especially in terms of financial capital. However, as reflected in the natural asset endowment, all households make use of natural resources. High-income households hence do not entirely drop resource-based activities, but seem to preserve a part of the traditional lifestyle rooted in the natural environment. Furthermore, $77 \%$ of the high-income households own modern housing as compared to $13 \%$ of low-income households.

Regarding livelihood outcomes, expenditures confirm this stratified picture, even among generally more welloff households (see Fig. 4). By conducting more in depth interviews with six households in the 3rd and 4th quartile of income distribution, we found average cash expenditures of US\$229 per month and household. However, expenditure composition varies considerably depending on household income. For those households below the Seronga average household income (average annual income of US\$1,700 as compared

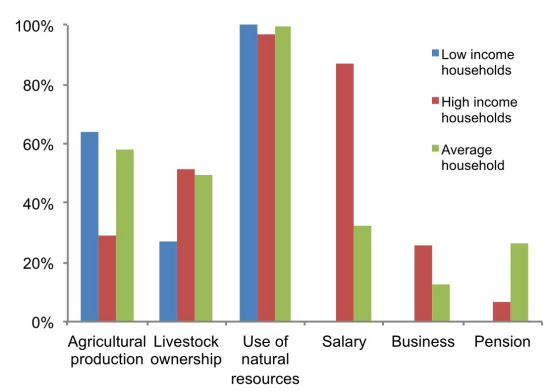

Fig. 3: Share of low income, high income and average income households practicing livelihood activities. 


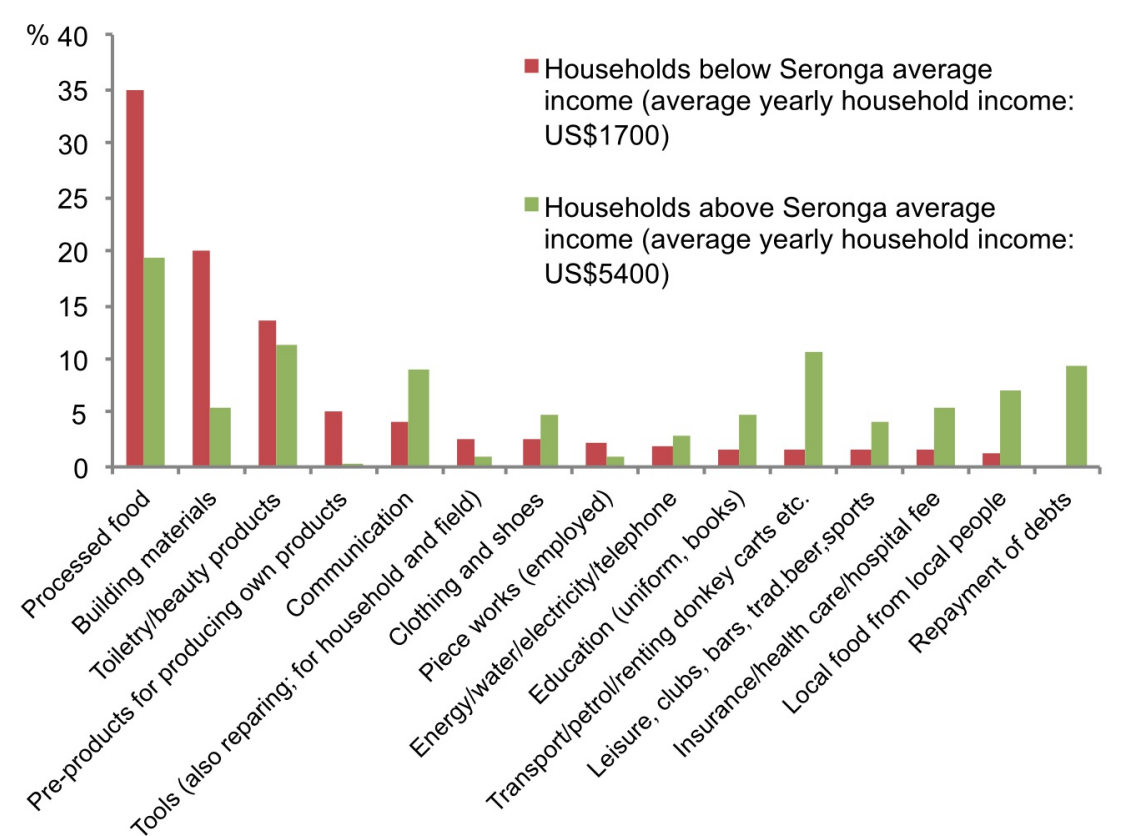

Fig. 4: Average share of expenses of households above and below Seronga average income (US\$2,911 per year and households based on SEBS) from six ethnographically interviewed households.

to US\$2,948) the main share of income is spent on processed food $(32 \%)$, building material $(20 \%)$, and toiletry/beauty products $(14 \%)$. Households with above average income (average annual household income of US\$5,400) spend a much smaller share of total expenditures on processed food $(18 \%)$ and toiletry $(11 \%)$. In turn, they spend more money on additional categories such as transport/petrol (11\%), repayment of debts $(10 \%)$ and communication $(9 \%)$. Building material, however, only accounts for $5 \%$ of the total expenses. Despite the small sample size, these findings imply that with rising income, households (1) tend to diversify expenditures, (2) become geographically more flexible and (3) become able to buy on credit and gain access to external cash sources. Access to funding combined with know-how and willingness to take risks are crucial prerequisites for the establishment of a private business. Additionally, less well-off households seem to devote a higher share of income to the construction of long-lasting, nonnatural resource based housing.

\section{Risk and vulnerability}

The overall capital endowment situation places the people of Seronga in a situation of 'semi-modernity': While many attributes of a modern lifestyle are generally available, their supply and payments for the culling of their cattle in viable projects. Most frequently, the money was used to purchase household items (Kgathi et al. 2007, Bendsen 2002).

Human wildlife conflicts in Seronga occur mainly in the form of killing of livestock, damage of crops and assets and loss of human lives by wildlife. Farmers lost 167 domestic animals in 2011 and 199 in 2010 to wildlife (Wildlife Office in Seronga, 2011, cited by Eigner 2012). Regarding damage of crops by wildlife, the most problematic animals are elephants. Eigner (2012) estimated the loss of crops to elephants at $30 \%$. This, again, creates more vulnerability for lowincome households with limited activity portfolios and high reliance on subsistence production. Despite the problem of human-wildlife conflict and its associated costs, it is worthy to mention that wildlife resources provide benefits in the form of use and non-use values. As already stated, SEBS has revealed that there are direct use values from wildlife resources in the study area in the form of employment and income generated by community-based and private tourism.

In addition to drought, animal diseases and human-wildlife conflict-related shocks, people of Seronga are affected by the HIV/AIDS pandemic. However, the adverse effects of this shock could currently be less severe as compared to about ten years ago as a result of the introduction of free antiretroviral treatment. Reporting on the results of a study undertaken in 2003, Kgathi et al. (2007) revealed that the people of Seronga and other villages in Ngamiland perceived the HIV/AIDS pandemic to be "the most devastating shock they had ever experienced". The pandemic depleted the financial resources of households and also negatively affected agricultural production due to its reduction of labor as a result of increased morbidity and mortality of the prime age adults (Kgathi et al. 2007).

Climate change is another factor, which may increase households' vulnerability. A number of scholars have argued that there is a possibility that reduced rainfall and changes in flooding patterns of the Okavango River may be additional stresses that may adversely affect rural livelihood activities in the future as a result of climate change, increase in irrigation projects and hydropower development in the upstream countries of Namibia and Angola (Wilk \& Kgathi 2007; Murray-Hudson 2009). 
These changes in flooding patterns may not only adversely affect natural resource-based livelihood activities such as those of arable and livestock farming, fishing, basket-making, and collection of veld products but also tourism activities in the long run as they depend heavily on the ecosystem of the Delta. Transboundary political measures are thus required for future developments.

\section{Transforming structures and processes}

Access to livelihood activities in Seronga is mediated by a number of factors, including policies, regulations, social relations and organizational structures.

\section{Land Tenure and Social relations}

The SEBS has revealed that policies aiming at conserving the natural environment also create social costs and transform people's livelihoods. Regulations of natural resource access and use sometimes restrict income generation and subsistence opportunities. Therefore, regulations such as the prohibition of fishing during breeding season and tree cutting during the early winter months, as well as the ban of hunting are perceived to be patronizing rather than beneficial, though in the longterm they may secure the sustainability of the natural resource base which is the fundament of the population's subsistence.

Land tenure in particular regulates the access of households to natural resources (wildlife and other collected items). The Okavango Community Trust (OCT), as a CBNRM (Community Based Natural Resource Management), was allocated rights on two concessions (NG23 and NG22). The concessions are now operated in joint-venture by a private tourism company. Access to these zones by the population and livestock of the villages is restricted.

Further, land-use zoning policies on veterinary fences are perceived to adversely affect livelihood activities. Consequently, households of the greater Seronga area (which includes surrounding villages such as Gudigwa) suffer from reduced access to veld products collection and grazing resources. It also restricts the Okavango Polers Trust (OPT) in its tourism activities, as it does not have access to concessions NG22 and 23 and it has to conduct tourism activities in the communal areas used by all community members. The OPT struggles against the private competition, as tourism relies on pristineness and wildlife presence. In addition, the fence has increased the number of wildlife; hence it has increased predation of livestock by wildlife in the area (Kgathi et al. 2004).

Land zoning may, however, contribute to finding a solution to part of the humanwildlife conflicts. There is a general concern that there are too many elephants in Ngamiland. However, recent considerations look at the distribution of fields and the missing corridors for elephants between the bush and the delta as a potential origin and solution for these conflicts (Chase 2011). Currently land use zoning into cropping zones, building zones, forest zones and corridors for wildlife are being undertaken as a pilot study in Seronga (pers. Comm. Land Board Seronga 2013).

Further international policies impact the local life in Seronga. Despite intensive animal health controls and vaccination campaigns, Seronga's embeddedness in a web of natural parks and the relative permeable buffalo fence prevent the region from gaining the status of a foot and mouth disease free area in the short and middle term. This hinders attractive export options for beef to the EU market, although there has never been an outbreak in Seronga itself (personal comm. Department of Agriculture, Maun, 2013).

A further mediating factor is social relations, which mediates access to livelihood activities in Seronga and nearby villages. According to Kgathi and Motsholapheko (2011), the people of Gudigwa in the greater Seronga area, who are mainly of the Basarwa ethnic group, were of the opinion that the benefits of the OCT benefited other ethnic groups more than themselves. As a result of limited access to CBNRM, $67 \%$ of the households wanted the old practice of special game hunting licenses to be restored so that they could have more access to meat. They consider eating meat as part of their cultural identity (Kgathi and Ngwenya 2005). Apart from ethnicity, the other factor, which mediates access to livelihood activities in Seronga is gender. The low-income households in our analysis are majorly composed of female-headed households $(58 \%$ as compared to $17 \%$ of high-income households).

\section{Governmental support}

In general, the government plays a major role in ameliorating the adverse effects of shocks on livelihoods. Both during the drought and animal epidemic, it provided considerable support: People were provided with seeds, food, livestock, and employment. In 1999, $62 \%$ of the Ngamiland population relied on government support in some way (Bendsen 2002). Through the provision of social welfare programs, education subsidies, free basic medical care, agricultural support, Ipelegeng, and volunteer jobs the government actively subsidizes people's livelihoods. Many of these measures particularly benefit the vulnerable low-income population.

At the same time, the state sets incentives to transform livelihoods in order to achieve long-term sustainable economic development. Besides fostering market integration of livestock and crop producers, the government has introduced the Youth Development Fund to support startup businesses.

\section{Tourism}

Additionally, the state supports the development of the tourism industry. According to the Botswana Tourism Master Plan, efforts to increase the share of the tourism sector in Botswana's GDP (Ministry of Commerce and Industry 2000) are strongly motivated by national objectives such as the increase of foreign exchange earnings and government revenues, as well as the fostering of rural development. The geographical location of Seronga offers promising perspectives for local tourism development. Apart from government institutions, the tourism industry is the main employer in Seronga at present. Household members with regular employment actively invest. They build modern houses (sometimes with water and electricity infrastructure), and buy furniture and electronic equipment. This can create positive spill-over effects as other family and community members benefit from the increasing dynamic in development. However, qualitative interviews and informal discussions reveal that wages in the tourism sector are perceived as too low, compared to the earnings of the private tourism operators. Furthermore, 'wage dumping' seems to be a problem for local polers. Apart from monetary complaints, people miss trickledown effects of knowledge from working in tourist companies (e.g. in form of 
apprenticeships). The loss of traditional culture that is perceived to accompany modernity additionally threatens many of the informants.

Besides private tourism operators, the Okavango Polers Trust is the only local and in some respects 'community based' tourism business in Seronga. However, due to organizational and economic problems, the OPT was recently rented out to a private tourism operator (pers. Communication, Chairman OPT 2013). Although community based organizations (OPT and OCT) have the objective to distribute tourism revenues more widely among the community, they fail at present to generate significant benefits for the overall population. The reasons are manifold. There are over-expectations by the people, partly paternalistic attitudes by the community-based organizations themselves and difficulties to retain welltrained managing staff in the long run. In addition, typical challenges regarding the management of common pool resources can be observed. Members are sometimes passive in contributing to the organization, but expect to seize the (monetary) benefits. In this regard, failed expectations have the potential to create a feeling of oblivion and abandonment among the villagers.

Despite a number of transforming structures, there is at least one major factor restraining Seronga's future development. The village is classified as a Tertiary Center II in the frame of the National Settlement Policy, which provides a set of guidelines for national physical planning (Kgomotso and Swatuk 2007). It is mainly due to Seronga's current status as a community of less than 4,999 inhabitants that further infrastructure development such as the construction of a tarred road, the connection of the village to the national minibus system, the drilling of a second borehole and the construction of a senior secondary school is currently not planned.

\section{Discussion and Conclusion}

This paper utilizes the Sustainable Livelihood Framework to examine the way people make a living in the village of Seronga in Botswana. Furthermore, the analyzed data gives insights on how access to cash income affects rural livelihoods.

\section{Effect of cash income on rural livelihoods}

The analysis of livelihood capital assets showed that although most of the households had access to the basic needs, ownership of most capital assets varied strongly depending on access to monetary income (salaries, business, and pensions). Household's access to social, physical, and financial capital assets seems to be positively influenced by higher education levels. However, natural capital was not restricted to any socio-economic group.

While livelihood activities in Seronga are both natural resource-based and nonnatural resource-based, the former tend to dominate, particularly among the poor. Our results also indicate that, especially with rising incomes, households in Seronga diversify their livelihood activities (see also Ashley and Maxwell 2001). The majority of the households in this village, low- and high-income, still rely on their own agricultural production and the natural resource base serves as an insurance for households that try to establish less natural resource based livelihoods. These findings are consistent with the literature on other parts of Botswana (Kgathi et al. 2011; Motsholapheko et al. 2012). A study undertaken in the six sub-Saharan African countries of Ethiopia, Nigeria, Tanzania, Malawi, Zimbabwe and South Africa during the period 1996-8 revealed that non-farm rural activities accounted for $60-80 \%$ of the rural household income. It is also noted that rural households are increasingly becoming less committed to farming (Bryceson 2002; Rigg 2006). However, employment opportunities in the private sector remain largely limited to private tourism operators and, in the public sector, dependent on governmental institutions.

\section{Shocks, vulnerability and sustainability}

Due to these differences in livelihood composition, households are differently affected by shocks, stresses, and the prevailing structures. Also, their capacities for resilience and thus sustainability are dependent on their position on the socio-economic stratum as well as their livelihood diversification.

The low vulnerability of high-income households concerning the basic need of food supply is expressed by the fact that they more frequently renounce to arable agriculture. Cropping is an activity which is characterized by poor returns (Eigner 2012), but that is necessary if households have no alternative access to food. Advanced endowment with physical capital and the opportunity to (re)invest for instance in livestock - are other ways for high-income households to buffer shocks. However, it must be noted that the cattle population in Seronga, although skewed, is already very high (Eigner 2012) and is considered by stakeholders of high administrative levels to be a threat to the savannah ecosystem (pers. comm. SAREP 2013). This hints towards a problem with the long-term ecological sustainability of this livelihood strategy. In contrast, low-income households are less educated and more often femaleheaded. They have less access to information as they less frequently own radios, cell phones and TVs. They often have neither cattle nor plough to increase their farming productivity, although subsistence food production is their livelihood basis. Borrowing from other people further increases their dependence. They depend on pensions and low paid irregular wage work for cash income, which they spend on basic vital items (shelter and self-care) as well as for complementing the subsistence food production. Hence, they are not only more exposed to shocks of droughts and stresses such as climate change, but they also have fewer alternatives to maintain a living.

Apart from piece jobs and governmental support, one alternative, for generating cash, consists in the retail of natural resources, which holds true especially for the average-income households. This can be a growing concern for the ecological sustainability of the system in the future, especially if certain circumstances as e.g. better infrastructural connections develop: cash may become more important than local natural resources as it can replace them on the short term. On the long term though, over-harvesting and sociocultural transformations may threaten the cultural and the ecological system and its sustainability.

Indeed, at the scale of the government, the development of tourism in Botswana currently comes with a strong focus on ecological conservation. On the one hand, they favor wildlife, and thereby foster employment opportunities in the administration and tourism sectors: however, only well-off households with a high education level that are already better-off benefit. On the other hand these 
policies set limits to traditional lifestyles. Restrictions around natural resourcesdependent livelihoods and simultaneously the transformation pressure for the participation in a cash-based society increase. Consequently these policies have a double negative impact especially on the adaptation capacity of poor households, strongly affecting the sustainability of the whole socioecological system (pers. comm. with University of Botswana and NGO NCONGO, 2013).

Government policies regarding high quality tourism with low tourism flow and low impacts may well be sustainable at the scale of the nation but locally, they strongly disfavor local tourism and initiatives, as we illustrated with the case of the OPT in Seronga. Thus, tourism policies currently have a quite limited positive local spill-over and do not address the livelihoods of the very poor.

Government measures including e.g. the provision of free seeds, compensation to wildlife related losses, etc. aim to improve livelihoods. However, such measures rather stabilize livelihoods by providing immediate relief. They fail to foster the adaptation and flexibility of poor households - characteristics they need to acquire in order to sustain independently in the long term. This form of support might create path dependencies and limit incentives to escape the poverty trap (e.g. in Domptail et al. 2013). However, both the dependency on governmental support of poor households and the dependency on very few employers by the better-off households (government and tourism companies) depict vulnerabilities or insecurities, which at the moment can only be met by a diversification of livelihood strategies.

These insights indicate that there seems to be a mismatch between transformation pressures and the local business dynamics, which especially holds true for non-tourism businesses. There exist a few well-run businesses, but the spirit of entrepreneurship is marginal. It is the task of policy makers to take these insights into account when designing new policies and development programs that aim to support people's livelihoods.

\section{Acknowledgements}

This study was part of The Future Okavango project, which is funded by the German Federal Ministry for Education and Research. Special acknowledgement goes to the surveyed community members for their time, assistance and hospitality. We would like to acknowledge the crucial role of the following TFO researchers in collecting and processing SEBS or ethnographic data: Matthias Legler, Nna Maeze, Olebogeng Samaemo, Onkabetse Tomologho, Ketobihile Twaimango, Meshack Kwamovo, Matoka Montshonyane and Nthobatsang Ndoze. We would like to thank Christian Fischer for the support of graphical analysis, as well as Michael Pröpper and Michael Schnegg for their valuable inputs and revisions of the text. Lastly, we would like to thank two anonymous referees for their valuable input.

\section{References}

Ashley, C, Maxwell, S. (2001): Rethinking rural development. - Development policy review 19(4): 395-425. CrossRef

Ashton, P.J., Turner, S. D., Jensen, K. H., Mundy, P. J., Neergaard, B. B. (2006): Development of a Five-Year Research Strategy for the Okavango Delta Management Plan (ODMP). Contract Report for the Okavango Delta Management Plan (ODMP) Secretariat. - Maun (Botswana): Scanagri A/S, Copenhagen, Denmark. Xiv + 101 pages.

Barrett, C.B., Reardon, T., Webb, P. (2001): Nonfarm income diversification and household livelihood strategies in rural Africa: conepts, dynamics, and policy implications. - Food Policy 26: 315-331.

Beck, U. (2000): What is globalization? Cambridge: Polity Press.

Bendsen, H. (2002): The dynamics of the land use systems in Ngamiland. Changing livelihood options and strategies. - Maun: Harry Oppenheimer Okavango Research Centre and German Development Service (DED). URL: http://www.orc.ub.bw/downloads/ Bendsen2.pdf.

Bryceson D.F. (2002): The scramble in Africa: Reorienting rural livelihoods. World Development 30(5): 725-739. CrossRef

Bryceson, D.F. (1996): Deagrarianization and rural employment in sub-Saharan Africa. A sectoral perspective. - World development 24(1): 97-111. CrossRef

Bryceson, D.F. (1999): Sub-Saharan Africa Betwixt and Between: Rural Livelihood Practices and Policies. - Leiden, ASC Working Paper 43. - URL: https://openaccess.leidenuniv.nl/bitstrea $\mathrm{m} / \mathrm{handle} / 1887 / 12912 / \mathrm{ASC}-075287668$ 022-01. pdf? sequence $=2$
Baumann, P. (2000): Sustainable livelihoods and political capital: Arguments and evidence from decentralisation and natural resource management in India. - London: Overseas Development Institute. Working Paper 136. - URL: http://www.mtnforum.org/sites/default/fil es/publication/files/3367.pdf

Botswana Central Statistics Office (2011): 2011 Botswana Population and Housing Census Alphabetical Index of Villages. URL:

http://www.cso.gov.bw/media/2011\%20 Census\%20_Alphabetical\%20Index\%20 Population\%20of\%20Villages.pdf and URL: http://ecastats.uneca.org/aicmd/ Portals/0/Census\%202011\%20Prelimin ary $\% 20 \% 20$ Brief $\% 20$ Sept $\% 2029 \% 2020$ 11.pdf

Carney, D. (1998) [Ed.]: Sustainable rural livelihoods: what contribution can we make? - London: Dept. for international Development.

Central Statistics Office (2004): Household Income and Expenditure Survey 2002/03. Main Report Volume 1. Gaborone.

Chambers, R., Conway, G. (1992): Sustainable Rural Livelihoods: Practical concepts for the 21st Century. Brighton: IDS Discussion Paper 296.

Chase, M. (2011): Dry season fixed-wing aerial survey of elephants and wildlife in northern Botswana. - Kasane: Elephants Without Borders.

Department for International Development, DFID (2001) [Ed.]: Sustainable livelihood guidance sheets. Edited by The Department for International Development. - $\quad$ URL: http://www.efls.ca/webresources/DFID_ Sustainable_livelihoods_guidance_shee t.pdf.

Domptail, S.E., Easdale, M.H., Yuerlita. (2013). Managing socio-ecological systems to achieve sustainability: A study of resilience and robustness. Environmental Policy and Governance 23(1): 30-45. CrossRef

Eigner, A.E. (2012): Socio-Economic Metabolism of a Village at the Confluence of Wildlife Management and Wetland Agriculture. - MSc. Thesis, in Agricultural Sciences, Nutritional Sciences and Environmental Management, Institute of Agricultural Policy and Market Research, Justus Liebig - University Giessen [deposited in the Institute and available by agreement of the author]

Ellis, F. (1999): Rural livelihood diversity in developing countries: Evidence and policy implications. - In Natural Resource Perspectives (40). - URL: http://www.odi.org.uk/sites/odi.org.uk/file s/odi-assets/publications-opinionfiles/2881.pdf.

Ellis, F. (2000): Rural livelihood diversity in developing countries. - Oxford: Oxford 
University Press.

Falk, T. (2008): Communal Farmers' Natural Resource Use and Biodiversity Preservation - A New Institutional Economic Analysis from Case Studies in Namibia and South Africa. - Göttingen: Cuvillier Verlag.

Hahn, H. P., Spittler, G., Verne, M. (2008): How many things does man need? Material possessions and consumption in three West African villages (Hausa, Kasena and Tuareg) compared to German students. - In: Hahn, H. P. [Ed.]: Consumption in Africa: anthropological approaches [workshop held at the African Studies Centre at Bayreuth University]. - Münster: Lit Verlag: 173-200.

Hamilton-Peach, J., Townsley, P. (2004): An IFAD Sustainable Livelihoods Framework. The International Fund for Agricultural Development (IFAD). URL:

http://www.ifad.org/sla/framework/index. htm.

International Fund for Agricultural Development (IFAD) [Ed.] (n.y.): The Sustainable Livelihoods Approach. URL: http://www.ifad.org/sla/index.htm

Kgathi, D.L., Bendsen, H., Blaikie, P., Mbaiwa, J., Ngwenya, B., Wilk, J. (2004): Rural livelihoods, Indigenous Knowledge Systems, and Political Economy of Access to Natural Resources in the Okavango Delta, Botswana. - Maun: Harry Oppenheimer Okavango Research Centre.

Kgathi, D.L., Ngwenya, B.N. (2005): Community based natural resource management and social sustainability. Botswana Notes and Records 37: 61-79.

Kgathi, D.L., Ngwenya, B.N., Wilk, J. (2007): Shocks and rural livelihoods in the Okavango Delta, Botswana. Development Southern Africa 24(2): 289-308. CrossRef

Kgathi, D.L., Motsholapheko, M.R (2011): Livelihood Activities and Income Portfolios in Rural Areas of the Okavango Delta, Botswana. - In: Kgathi, D.L., Ngwenya, B.N., Kwesi Darkoh, M.B. [Ed.]: Rural livelihoods, risk and political economy of access to natural resources in the Okavango delta, Botswana. New York: Nova Science. 35-54

Krantz, L. (2001): The sustainable livelihood approach to poverty alleviation: an introduction. - Stockholm: SIDA.

Little, P.D., Smith, K., Cellarius, B.A., Coppock, D.L., Barrett, C.B. (2001): Avoiding Disaster: Diversification and Risk Management among East African Herders. - Development and Change 32: 401-433.

Ministry of Commerce and Industry (2000) [Eds.]: Botswana Tourism Master Plan. Final Report. - URL:
http://www.ub.bw/ip/documents/2000_B otswana \%20Tourism\%20Master\%20Pla n.pdf

Ministry of Local Government (2011): Ipelegeng Programme. - URL: http://www.gov.bw/en/Ministries-Authorities/Ministries/Ministry-of-LocalGovernment-MLG1/Tools-andServices/Services1//pelegeng-Project1/ Motsholapheko, R.M. (2013): Rural households and adaptation to flood variability in the Okavango Delta, Botswana. - PhD Thesis, University of Botswana (Deposited at the University of Botswana Library).

Murray-Hudson, M. (2009): Floodplain Vegetation Responses to Flood Regime in the Seasonal Okavango Delta, Botswana. - PhD Thesis, University of Florida.

National Council on Population and Development (NCPD) (2010): Revised National Population policy. Improving the quality of life. Edited by NCPD and Ministry of Finance and Development Planning.

URL: http://botswana.unfpa.org/drive/Revised NationalPopulationPolicyBotswana(FIN AL).pdf.

Reardon, T. (1997): Using evidence of household income diversification to inform study of the rural nonfarm labor market in Africa. - World Development 25(5): 735-747. CrossRef

Rigg, J. (2006): Land, farming, livelihoods, and poverty: rethinking the links in the rural south. - World Development 34(1): 180-202.

Roberts, J.M. (1951): Three Navaho Households. A comparative study in small group culture. Cambridge, Mass: Peabody Museum of Americ. archaeology and ethnology (Reports of the Ramah project Report, 3).

Schnegg, M. (2009): It's the combination that counts: Diversification of Pastoral Livelihoods in Northwestern Namibia. In: Greiner, C., Kokot, W. [Eds.]: Networks, resources and economic action. Berlin: Pp. 229-247.

Scoones, I. (1998): Sustainable rural livelihoods. A framework for analysis. Brighton: Inst. of Development Studies (IDS working paper, 72).

Scoones, I. (2009): Livelihoods Perspectives and rural development. The journal of peasant studies 36(1): 171-196. CrossRef

Serrat, O. (2008): The sustainable livelihood approach. - Knowledge Solutions 15 (November). Manila: Asian Development Bank.

Smith, R.D., Gordon, A., Meadows, K. (2001): Livelihood diversification in Uganda: patterns and determinants of change across two rural districts. Food Policy 26: 421-435.

Statistics Botswana (2011): Botswana core welfare indicators (Poverty) survey of 2009/10 preliminary results. -
Gaborone: Statistics Botswana.

Swatuk, L.A. and Kgomotso, P.K. (2007) The challenges of supplying water to small, scattered communities in the lower Okavango Basin (L.O.B.), Ngamiland, Botswana: An evaluation of government policy and performance. Physics and Chemistry of the Earth 32 1264-1274. CrossRef

UNAIDS (n.y.): HIV and AIDS estimates (2011). - - URL: http://www.unaids.org/en/regionscountri es/countries/botswana/

United Nations (1987): Report of the World Commission on environment and Development 'Our Common Future'. URL:

http://conspect.nl/pdf/Our_Common_Fut ure-Brundtland_Report_1987.pdf

Van Dijk, Rejk (2010): Marriage, commodification and the romantic ethic in Botswana. - In: Dekker, M. and van Dijk, R. [Ed.]: Markets of well-being: navigating health and healing in Africa. - Leiden: Brill: 282-306.

Wilk, J., Kgathi, D.L. (2007): Risk in the Okavango Delta in the face of social and environmental change.

GeoJournal 70(2-3): 121-132.

World Bank (2012): World Development Report 2012. - Washington DC: World Bank.

World Bank (2013): School enrolment, primary ( $\%$ net) and School enrolment, secondary (\% net). - URL: http://data.worldbank.org/indicator/SE.P RM.NENR \& http://data.worldbank.org/ indicator/SE.SEC.NENR/countries

\section{Affiliations}

Björn Herold* (bjoernherold@me.com) Institute of Social and Cultural Anthropology, University of Hamburg Edmund-Siemers-Allee 1 20146 Hamburg, GERMANY

Laura M. Grosse*

(laura.grosse@wiwi.uni-marburg.de)

Macroeconomics, University of Marburg

Universitaetsstraße 24

35032 Marburg, GERMANY

Stephanie Domptail

(stephanie.domptail@agrar.unigiessen.de), Benjamin Kowalski (benjamin.kowalski@agrar.uni-giessen.de Agricultural and Environmental Policy

University of Giessen

Senckenbergstr. 3

35390 Giessen, GERMANY

Thomas Falk

(falkt@staff.uni-marburg.de)

Institute for Cooperation in Developing

Countries, University of Marburg 
Am Plan 2

35032 Marburg, GERMANY

Donald L. Kgathi (dlkgathi@ori.ub.bw)

Okavango Research Institute

University of Botswana

Private Bag 285

Maun, BOTSWANA

Nadege Azebaze

(nadege.azebaze@wiwi.uni-marburg.de)

Microeconomics, University of Marburg

Universitaetsstraße 24

35032 Marburg, GERMANY

*Corresponding authors 
